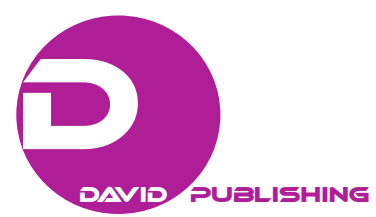

\title{
International Trade, Entrepreneurship, and Monopolistic Competition: German Hidden Champions and Global Markets
}

\author{
Arto Lahti \\ Aalto University, Helsinki, Finland
}

The Chicago School of Monetarism dominates the debate on the competition models. In the last decades, the pendulum has swung back towards the German historical school of economics by List, Schumpeter, Gutenberg, and Simon. The new trade theory by Paul Krugman is the standard in analysis of economies of scale and product differentiation in intra-industry trade. Chamberlin's product differentiation concept and monopolistic competition theory are included in Krugman's theory. Diversity matters in B2B-business in global markets. About 100,000 multinational corporations (MNCs) dominate the international trade of commodities worldwide but they need partners as suppliers of complementary products, services, and technologies. German hidden champions (HCs) that consist of over 1,300 mid-sized firms (Mittelstand) have revolutionizes the managerial economics. In terms of Peter Drucker, striving for leadership is the greatest gamble. Their success rate has been about $90 \%$ as Hermann Simon has reported. Their success recipe is the humble choice of markets segments, mainly B2B-industries, to make good business in any kind of goods and articles, not to follow trends or hit lists. The dilemma in EU-27-countries is that only Germany has succeeded to develop its own management doctrine initiated by Friedrich List and modified by Joseph Schumpeter. List argued that economic policy had to be adapted to the needs of specific nations to create the national system of innovation. Germany is the most diversified country worldwide. German small and medium-sized firms (Mittelstand) are globally oriented. Germany's family business is the unbelievable success story. Alfred Chandler has been a highly influential business writer. Because of Chandler's view, the personal capitalism was generally thought to be the old-fashioned model in comparison to the stock market capitalism. The Germany case is the strong evidence on the fact that Chandler's famous conclusion may be wrong. The family-ownership is perhaps the most sustainable governance model in the global economy. The US is the winner of Chandler's stock market capitalism, but the majority of US firms are domestic-market-oriented. In Germany about 100,000 mid-sized firms have experiences about FDI-operations.

Keywords: hidden champions (HCs), industrial organization (IO) economics, new institutional economic (NIE), new trade theory, intra-industry trade, monopolistic competition, multinational corporations (MNCs), global markets

\section{Introduction}

Friedrich List was the forefather of the German historical school of economics. List (1841) made a clear distinction to the Anglo-American classical (Smith, 1776; Ricardo, 1817) by his axioms: (1) A nation's true

Arto Lahti, Ph.D., professor, Department of Management Studies, School of Business, Aalto University, Helsinki, Finland.

Correspondence concerning this article should be addressed to Arto Lahti, Department of Management Studies, Aalto School of Business, P.O. Box 21230 (Lapuankatu 2) FIN-00076 AALTO. Tel: +358-50-376 9428. E-mail: arto.lahti@ aalto.fi. 
wealth is its productive power, rather than its current exchange values; and (2) private economic interests must be subordinated to the strengthening of the nation. List advised Germany and the U.S. to develop education, railways, and technology. List's ideas have been the basis for three economic miracles (Wirtschaftswunder) in Germany: (1) Zollverein from 1834 to 1919, (2) West Germany from the 1950s to the 1960s, and (3) globalization of Germany since 1990s, related to the completion of the vision of European economic integration by Bundeskanzler Konrad Adenauer (Wintle, 2002).

Schumpeter did not accept the interpretation of the Walrasian process of adaptation (Samuelson, 1947) in which economic agents (suppliers, consumers, etc.) are rational optimizers. Schumpeter $(1934,1939)$ analyzed economic development and business cycles. He claimed that an innovative transformation in a capitalistic society is a slow and conflict-ridden process (Schumpeter, 1942, 1994; Andersen, 2009) in which the entrepreneur is the hero of the drama (see Lintunen, 2000). Schumpeter introduced the concept of temporary monopoly profit as the lifeblood of innovativeness. As Frank Knight, the founder of the Chicago School (Institutional), Schumpeter was convinced that the so-called normal profit by neoclassical economics is not a satisfactory compensation of innovations and risk-taking under market circumstances of immeasurable unknown or true uncertainty (Knight, 1920). Innovations are the main driver of economic progress and welfare. There are two different innovation mechanisms (Lahti, 2010, 2012):

(1) Creative destruction is associated with radical innovations entering unexplored market where there are low entry barriers for new entrants that utilize the public domain knowledge. This is a microeconomic process by its nature and has strong macroeconomic implications for economic growth (Aghion \& Howitt, 1998; Romer, 1989, 1990).

(2) Creative accumulation is associated with organized R\&D that MNCs carry out innovation along established technological trajectories. MNCs dominate about $2 / 3$ of R\&D investments and about $80 \%$ of international commodity trade worldwide. As market leaders, MNCs have impact on industry life cycles and market structures (Scherer, 1999) and on rules of the game in global markets (Arrow \& Hahn, 1971).

Schumpeter (1934) argued against Marshall who in the early 20th century was the most intelligent economist of the British Economic School. Marshall (1920) exerted great influence on the development of economic thought and initiated the revolution of marginalism. His contributions include two concepts: marginal utility and representative firm. Marshall made the distinction between (1) external economies-economies of scale that depend on the firm's ability to grow to the optimal scale, and (2) internal economies - economies of scope that depend on the firm's resources, organization, and management efficiency. Schumpeter never denied Marshall's merits as the forefather of managerial economics. His main concern was that Marshall excluded entrepreneurial (innovative) behavior from the frame of neoclassical economics. When Marshall believed in the rational mind of managers, Schumpeter gave more credits to human agency.

Chamberlin (1933) and Robinson (1933) are regarded as the parents of the modern study of imperfect competition. Chamberlin (1933, 1937, 1948, 1951, 1957, 1965) provided the building block for Schumpeterian analysis of market dynamics by his theory of monopolistic competition (Brue \& Grant, 2008). Their collaboration contributed a lot to the modern economic thinking. Chamberlin's main contribution was the highly intellectual theory of monopolistic competition that is widely applied as the foundation of two important doctrines of international business: marketing (parameter) theory and the Structure-Conduct-Performance (SCP) paradigm. 
According to a narrow definition, industries with market structures similar to monopolistic competition include e.g. clothing, shoes, and services. According to a broad definition, it is possible to include most of the B2B-industries in international intra-industry trade. Monopolistic competition is the most common model of competition in globalizing markets and 60\% of the total (Figure 1). In Krugman's writings $(1979,1980,1981)$ on intra-industry trade, monopolistic competition and product differentiation are the main drives of trade. So Chamberlin's contribution has been fundamental to the trade-driven global economy, although not accepted by most of orthodox economists.

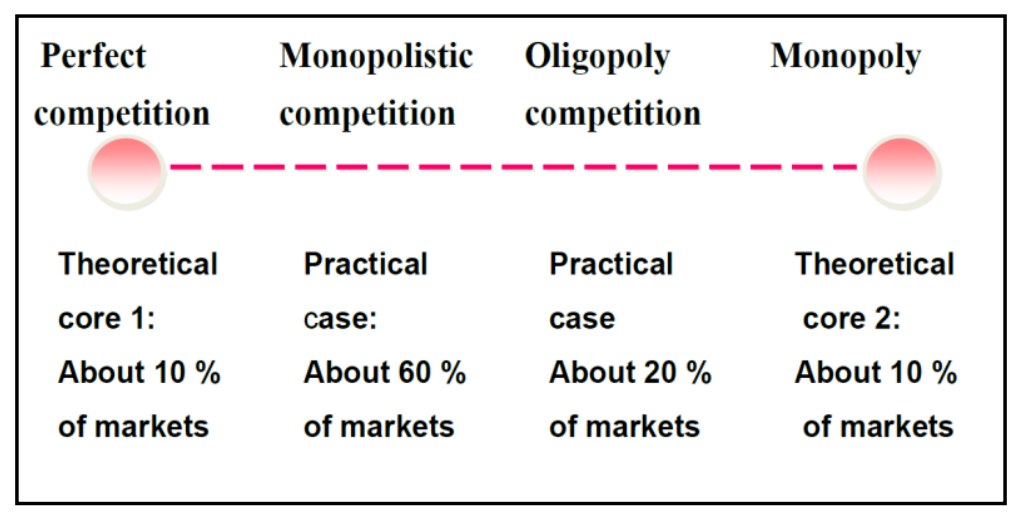

Figure 1. Competition and globalizing markets.

Germany has nearly four million firms that have taken advantage of monopolistic competition even in B2B industries that are commonly assumed to be stacked in the keen prices competition and in the continuous cost-minimization according to Marshall's idea. The main hypothesis of this article is: German HCs are winners of the B2B-industries, because they have innovated unique business models that in market behavior follow the key principles of monopolistic competition.

\section{Monopolistic Competition: Realistic View of Global Competition}

A monopolistically competitive firm generates brand loyalty and other elements of differentiating marketing activities and thus faces a downward sloping demand curve. Due to the wide availability of substitutes, the demand curve in various globalizing markets tends to be relatively elastic. In a monopolistic competitive industry, there are many firms or many competing products that are close substitutes in nature and many specialty brands. The differences in the brands are either actual or perceived. In the short run, the firm will maximize profit in the point where marginal cost $(\mathrm{MC})$ equals marginal revenue (MR). Average revenue may exceed average cost (AC). In the short run, firms may make supernormal profit (Figure 2).

Super-normal profits attract new entrants, which shifts the demand curve for existing firm to the left. In the long run, supernormal profits are competed away by new entrants. This shifts the average revenue curve to the left until eventually average revenue (AR) is equal to AC and the firm will earn the so-called normal profit. Unlike a perfectly competitive firm that produces at the minimum point of its total AC curve, a monopolistically competitive firm produces at the point where AR equals MC that is the long-run equilibrium (Figure 3). In monopolistic competitive markets, none of these firms faces the entire demand curve in the way a monopolist would do, but each does have some power to set prices. 
Short Run

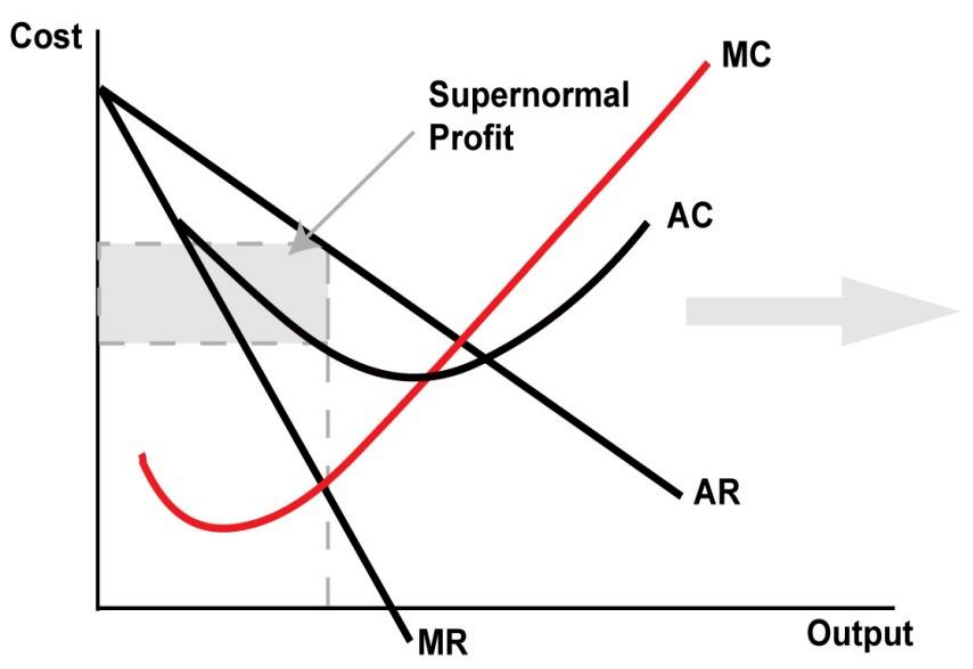

Figure 2. Monopolistic competition-from short run to long run.

\section{Long Run}

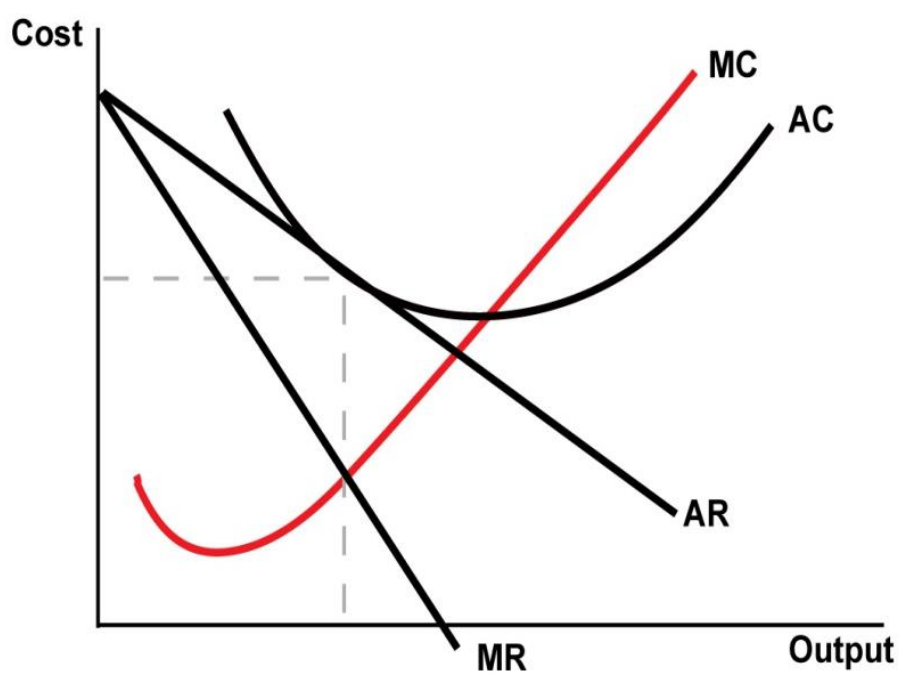

Figure 3. Monopolistic competition-long run.

In international trade, there are only few products that in broad terms are homogeneous. Therefore, the monopolistic competition theory is useful. Chamberlin's most intelligent idea is that monopolistic competition includes characteristics of two (orthodox) models of competition: perfectly competition and monopoly. Monopoly was exposed by Antoine Cournot (Sandmo, 2011) and elaborated by Marshall (1920). Chamberlin's idea is that any different strategy of a firm's product gives it to an edge of monopoly. Schumpeter's idea is a temporary monopoly profit that is related to an edge of monopoly in innovations. Chamberlin argued also that marketing costs are not a part of the cost of production, but are incurred to increase the sales of the given product and, thus, they affect the demand curve. In the same way, $R \& D$ costs shift the demand curve, although the impact is more dynamic. In the model (see Figure 2 and 3), a monopolistically competitive firm faces a 
downward sloping demand curve in the same way as a monopoly firm (Goodwin, Nelson, Ackerman, \& Weisskopf, 2009). Unlike a monopoly market, a monopolistically competitive market is open for entry of firms (Krugman \& Wells, 2009) and, thereby, contestable in the long run, comparing to Baumol (1982).

International trade has contributed strongly to the GDP of nations. The export-led growth has been a key part of China's success during past decades. Chamberlin's most visionary argument is: Monopolistic competition is welfare enhancing, not reducing since a society gets as much product diversity as it is willing to pay for (Bellante, 2004). Diversity matters in global markets. As expected, Chamberlin challenged the leading neoclassical economists by claiming that most of the economic situations are composites of both competition and monopoly, and that, wherever this is the case, a false view is given by neglecting either one of the two forces and regarding the situation as made up entirely of the other (Chamberlin, 1937, 1965). In a monopolistic competitive industry, there are relatively many products that are close substitutes not perfect substitutes. The differences among competing products are either actual or perceived. In global markets, there are potentially millions firms supplying products that are close substitutes. Therefore, perfect competition is not possible and monopoly is temporary as both Chamberlin and Schumpeter have claimed.

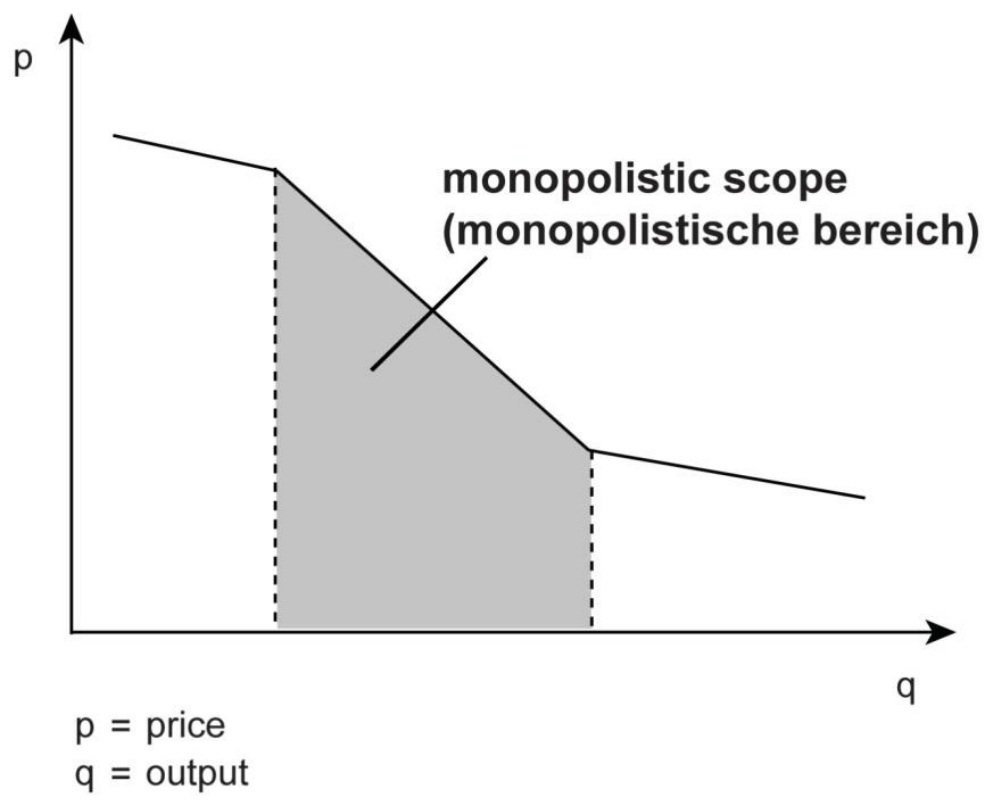

Figure 4. Gutenberg's price theory.

Chandler $(1962,1990)$ emphasized the role of general management in the transformation of a firm's strategy and structure (Kreikebaum, 2000; Albach, 1980). In Gutenberg's solution, the individual price-sales function is doubly kinked and a firm has its own monopolistic scope of the price-sales-function to plan its marketing parameters, without having to fear reactions of competitors (Figure 4). When a firm leaves the monopolistic scope, the price is dictated by the market (Pindyck \& Rubinfeld, 2009). Gutenberg's price theory has been important for German firms that are aware of how import price positioning is in global markets. The monopolistic scope concept is genius and visual even for small and medium-size enterprises (SMEs). The success story of German HCs (Simon, 2009) is probably based on their unique applications of the ideas of monopolistic competition. 


\section{Industrial Organization (IO) Economics}

The development of industrial organization (IO) economics as a separate field of micro-theory owes much to two Harvard professors: Edward Chamberlin and Edward Mason (1957), and Joe Bain who was doctorated at the Harvard. The IO is a broad field of studies that are built on the theory of the firm by examining the structures and boundaries of industries and markets (De Jong \& Shepherd, 2007). The IO adds multiple real-world imperfections to the competitive models, such as transaction costs (Coase, 1960, 1987, 1988, 1998), limited information (Simon, 1960, 1979), and barriers to entry of new firms (Bain, 1951, 1956) that are associated with imperfect competition models. Frederic Scherer, a Harvard professor, focused on dynamics in economics, e.g. technological change, leading to numerous publications. In 1970, he summarized the state of art of the Structure-Conduct-Performance (SCP) paradigm in his book of the topics (Scherer, 1970) that is widely thought to be the best book of the SCP ever written. The SCP paradigm assumes that the performance of an industry is determined by how firms in that industry conduct their activities in terms of the market structure. Scherer and Ross (1990, p. 5) summarized the relevant framework for the analyses of SCP (Figure 5).

The SCP is mainly developed by Bain $(1951,1956)$ to offer the causal explanation for the firm's conduct and performance in imperfect markets. The SCP paradigm revolutionized the IO studies. For the first time, it was possible to make empirical and statistical analyses of how firms are really behaving. The SCP finding was the key to the implementation of the anti-trust legislation in the US from the 1950s to the 1970s. The SCP provided new tools for the US governmental agencies, and, later, to the EU commission, to verify the antitrust rules. The main hypothesis of the SCP is: The degree of seller concentration is inversely related to the degree of competition (Bain, 1956). Barriers to entry, e.g. economies of scale, are the sets of economic forces that create disadvantages to firms that attempt to enter the market. The SCP is the most powerful analytical tool since (1) it is straightforward in its line of reasoning, and (2) it is highly useful in the identification of structural characteristics (Jones \& Sufrin, 2010).

In the 1970s, Caves began to modify the Chamberlin-Mason-Bain-Scherer SCP model of structure and performance to include differing positions of strategic groups of firms within industries. He redefined entry barriers (Bain, 1956) to mobility barriers that are persistent structural features, not only at a firm level, but also at a strategic group level, that give rise to structural/strategic and asymmetric mobility barriers protecting a given strategic group from the entry of potential rivals and, thereby, permitting performance differences among groups and, hence, among firms. He guided a serious of dissertations: Hunt (1972), Newman (1973), and Porter (1973). In the global markets, firms try to find out better positioning inside/in-between industries, which leads to structural changes in the whole industry in terms of Schumpeter. Parallel to that, the strategic management doctrine advises firms to make proactive decisions of their products, markets, and technologies (Hoskisson, Hitt, Wan, \& Yiu, 1999).

In the Purdue University, Dan Schendel and Arnold Cooper initiated the "brewing" studies (Hatten, 1974; Patton, 1976) to explore empirical links among organizational resource choices, interpreted as strategy, and firm's performance (Rumelt, Schendel, \& Teece, 1991). The strategic choice approach by Purdue-studies assumes that systematic similarities and differences exist among firms as a result of strategic resource choices, i.e. decisions to invest in assets which are often difficult and costly to imitate (McGee \& Thomas, 1986, 1989). While the Harvard studies relied on the cross-sectional data in econometric analyses, Purdue-studies used time-series data to draw valid inferences about the performance differences and patterns of competition of a 
single industry. A new contribution was the use of numerous variables linked to strategy to identify competitive or strategic groups selected within the context of the particular industry under study (Cool \& Schendel, 1987). The bottom-up approach by the Purdue-studies is suitable to even small firms, whereas the new Harvard approach is tailored to MNCs.

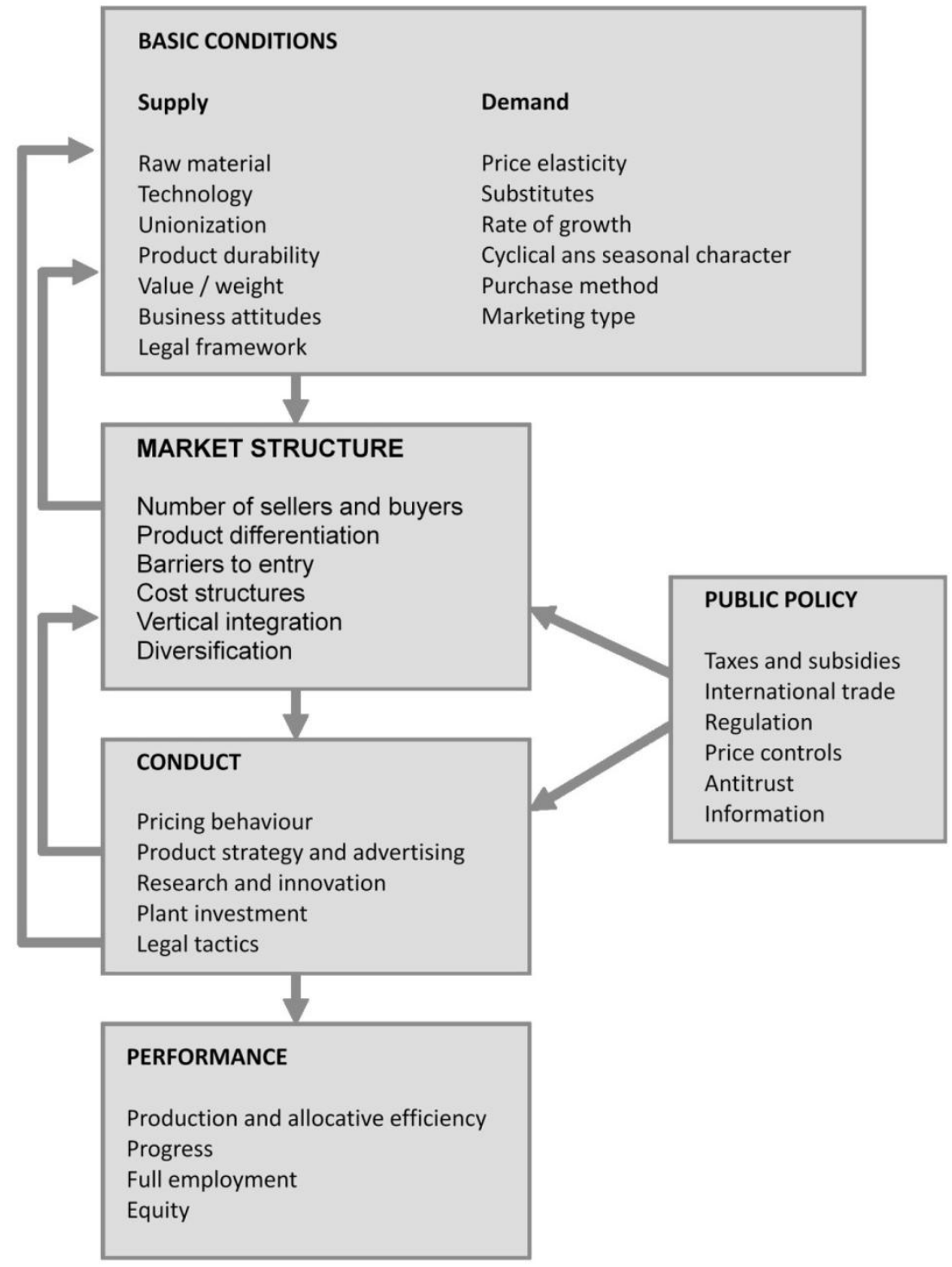

Figure 5. SCP model of Scherer and Ross.

The dilemma of the most studies under the IO is the methodology selected. Using solely cross-sectional data is not a correct approach since strategic groups are highly dynamic. According to the Finnish IO studies by Lahti (1983), Salimäki (2003), Killström (2005), and Luukkainen (2012), mobility barriers can explain some of sustainable performance differences among strategic groups and, performance differences exist among firms holding identical strategic positions within an industry (Carroll, Pandian, \& Thomas, 1994). In most of IO studies, the contribution of a strategic group to a firm's economic performance is weak (Thomas \& Venkatraman, 1988). The Finnish IO studies provided evidence that strategic groups are real, and not only 
constructions of researchers. This depends on the fact that the Finnish researchers have long experience of industries under investigation. The main findings are that the modern SCP/IO is highly useful to many kinds of industry and market analysis, but a careful analysis takes time.

Luukkainen (2012) analyzed the greenhouse sector in Finland and did a massive empirical study. He collected data of 121 greenhouse companies covering 11 years (1998-2008) and combined many possible sources of data. Together, he did 1,331 firm level analysis. In his study, the strategy process was applied to the greenhouse sector. In contrast to previous studies, Luukkainen's production function was employed in the identification of strategic groups within the field of operation. These groups occupy a central position in the analysis of the industrial context. The production function was used to simulate the system dependency of different combinations of productive input and output factors. The price and the capacity utilisation ratio of productive inputs are crucial as the firms' aims to achieve optimal results in its business environment. Luukkainen noticed that the profitability of the sector declined throughout the 11-year research period due to the import competition and a simultaneous rapid increase in the production costs. The rapid increase in production potential in Finland has resulted in overproduction in the small domestic market, and sufficient resources have not been channeled to the development of export.

\section{New Institutional Economics (NIE)}

The New Institutional Economics (NIE), coined by Williamson $(1985,1987)$, has its roots in the ideas of Ronald Coase. Like Schumpeter and Chamberlin, Coase (1960) questioned the relevance of the orthodox economics, because the language of mathematics due to the demands for determinacy is not designed to deal with complex semantic meanings (Samuels, 1989). Coase argued against the misuse of formalism in neoclassical economics that masks underlying contradictions in the theory. The lack of relevance to solve real world problems is the consequence. Following the idea of agency theory, human behaviour is not rational (Eisenhardt, 1989). Bounded rationality, moral hazards, and risk awareness characterize human behaviour more than assumptions of perfect rationality. Williamson discussed ex-post costs of transacting and Coase discussed the ex-ante costs of transacting.

The transaction cost concept is useful in global contexts. Ex-post contractual failures are salient when transaction costs are significant because of a firm's asset specificity and irrationality in human decision-making. Investments in specific assets need safeguarding, if opportunism arises aimed at the ex-post appropriation of income streams which are generated by the underlying specialized assets, e.g. licensing of patents or franchising brands. In principle, safeguarding against contractual hazards, such as an aggressive patent trolling activity, is difficult to implement in the international context without comprehensive contracting and high legal (transaction) costs. Patent trolling may be highly rewarding at least temporarily. The NIE defines the firm as the governance structure or the nexus of contracts - a view that contrasts fully with the orthodox theory of the firm (Williamson, 1990, 1991). The NIE's notion of contractual function of a firm is useful in global markets where a firm's function is its efficiency in market transactions not only in production as (Coase, 1998) elaborated in the NIE contribution.

In Loasby's thinking (1999), the rapid evolution in global economies is based on the growth of scientific knowledge and technology. The WTO treaty is an important catalyst of the scientific revolution. In the NIE terminology, each of institutions has its unique cognitive history. This is the main reason why the global economy under the WTO treaty is still a mosaic. The "rules of the game" are nation-specific or even 
clan-specific and sometimes reason-specific. In order to determine whether or not the transaction should be brought into the firm and to be taken out of the market, a firm should determine the frequency of the transaction under the conditions of uncertainty (Knight, 1920). When the uncertainty is high, vertical integration into an organization will be the most efficient mode of governance. This is the way how MNCs organize their global businesses.

The orthodox economics rely on competition to induce entry into the industry, since an entry of new firms provides the equilibrating function in the market to restore prices and profits to the competitive level. For the NIE, the most efficient firms are those that are able to enter a market and engage in the most specific transactions. In global markets, for example, a R\&D-project or a cross-licensing is a complex chain of transactions that is not possible to implement without a strong contractual capability. MNCs are the most powerful actors of corporate capitalism (Schumpeter, 1942), not only because of production efficiency but because of their excellence in global contracting (Kumar, 1990, 1994, 1998). Through their strategies, MNCs use to restructure their markets and the global rules of the game. Because of the scientific technology (knowledge) revolution in the globalized economies, the neoclassical theories of the firm do not function properly. As Schumpeter understood, such a theory would have to deal with entrepreneurship and innovation in the process of technological revolution (Lazonick, 1991, p. 126) in which the NIE's notion of efficient contractual function is useful especially to start-ups and growth companies.

North (1993) claimed that economic institutions are path-dependent. Therefore, states can never be treated as exogenous actors in development policy, since states have the mandate or territorial monopoly to set property rights and to enforce competitive market conditions. Property rights matter, because they influence a firm's markets. The major part of costs and rewards associated with the use of intellectual property rights (IPRs) and, notably the use of IPRs does accrue to the firms. Fortunately, IPRs have the respectable connotation of property, instead of the unpleasant monopoly privilege (Machlup \& Penrose, 1950). The Paris Convention for the protection of industrial property was established in 1883 and the Berne Convention for the protection of literary and artistic works was established in 1886, providing the internationally agreed frameworks for IPRs. The WTO TRIPS (Trade-Related Aspects of Intellectual Property Rights) agreement has established the standards of protection and the rules on enforcement, and brought the IPR regimes of the WTO member countries under the jurisdiction of the dispute settlement system of the WTO.

Knowledge is an important commercial commodity and the most profound characteristic of globalization. Universities are activated to the production of commercial knowledge for business purposes, following the University of California's role model. MNCs are actively involved with the universities and research labs in order to get access to the up-to-date scientific knowledge. The Mega-science themes, like the human genome project, are global in their basic nature since they can only be addressed on the global scale. The TRIPS is the main catalyst for the knowledge economy. Besides the TRIPS, the US innovation model is found to be the most "inspiring" institutional innovation globally (Haour, 2004; Loewenberg, 2009; Retrieved from www.economist.com/node/1476653).

The Bay-Dole Act (DBA), enacted in 1981, provides universities the first-right to commercialize patents, and, if they fail in that, the federal government retains the ownership of patents and then can grant non-exclusive licenses to interested third parties.

An institutional innovation was the liberalization of the federal antitrust laws to allow collaborating research projects of firms in the same industry: Stevenson-Wydler Technology Innovation Act of 1980. 


\section{New Trade Theory}

Ricardo (1817) is the father of the inter-industry trade theory. He was the first classical economist who developed the model of resource-based comparative advantage in international trade over regions. Ricardo used the opportunity cost theory. A country should specialize in production of that product (or service) whose cost for failure to produce is higher than that of the second alternative. A country would produce more of the two products than the other country (absolute advantage) or specialize in producing that product in which it has an advantage in utilization of the available resources (comparative advantage). Ricardo's concept of comparative advantage can be interpreted as a firm level competitive advantage of a firm's resources since a combination of firm-specific and country-specific resources is the means for the positioning in markets.

The Heckscher-Ohlin model (H-O model) (Ohlin, 1933) is built on Ricardo's model by predicting patterns of trade and production based on the factor endowments of a trading region. The model predicts trade patterns based on relative factor advantages. A country with a relative abundance of one factor is expected to produce goods that require a relatively large amount of that factor in their production. The original H-O model is an alternative explanation for free trade to Ricardo's model, rather than a complementary one. Ohlin understood the importance of the economies of scale that are external to the firm but internal to the industry or the region. Examples are skilled labor force and technological know-how. When economies of scale are significant, countries with few differences in technology and in production costs will gain from specialization in intra-industry trade in which countries trade similar, but differentiated, products with each other, e.g. different marks of cars.

The H-O-model is not generally accepted as a theory of trade. Empirical research has produced a number of results that do not match the logic of the model. Leontief (1986) tested the model in the US and found that a capital-abundant country exported labor-intensive and imported capital-intensive commodities. However, the problem of the so-called Leontief's paradox is not the H-O theory as such, but perhaps the concept of capital of orthodox economists. The US has its advantage in highly skilled labor. This can be seen as the intellectual capital. Using this definition, the exports of the US are human capital abundant, not particularly unskilled labor abundant. During the wartime, the US economy oriented towards innovations and human capital, which is the historical reason for the Leontief's paradox.

Linder tried to solve the Leontief's paradox, which questioned the empirical validity of the H-O-model, but did not solve it. Linder hypothesized (1961): Demand plays a more important role than comparative advantage in trade. In his model, a pattern of trade is determined by the aggregated preferences for goods within a country. Demand-based international trade arises from consumers' taste of variety. Countries with similar preferences are expected to have the same structures of industries. Aggregated tastes for certain product can emerge simultaneously worldwide which provides huge prospects for certain commodities (e.g. Nokia's mobile phones in the early 90s). Linder's demand-driven explanation is a complement of factor-driven explanations, because the supply side has dominated international trade theories.

Intra-industry trade means an increasing dependency on foreign markets (Foster \& Stehrer, 2013), when industries are able to source intermediates from different countries, an activity referred to "offshoring". Intra-industry trade has evolved as an important economic practice increasing the number of differentiated versions of the same type products in markets, which is beneficial to firms and consumers, and gives businesses chance to benefit from the economies of scale and as well as use their comparative advantages. Intra-industry 
trade stimulates innovation in industry (Krugman, Obstfeld, \& Melitz, 2012). The main benefit of intra-industry trade can be explained by using a car trade between Japan and Germany. Japanese cars are mainly family cars (e.g. Toyota), and German cars (e.g. Audi or BMV) are sport cars. Japanese and German car manufacturers can increase their global competitiveness by collaborating in non-core subcontracting and risk-sharing of radical technology, e.g., fuel cells.

According to Chamberlin, there are a lot of monopoly elements in international trade. Monopolistic competition theory of trade has been developed by Dixit and Stiglitz (1977), who analysed increasing returns and provided the foundations for the theoretical framework for combined analysing of economies of scale and product differentiation. The resulting interaction between demand for product variety and economies of scale leads to intra-industry trade (Helpman \& Krugman, 1985). To Krugman, increasing returns is the fundamental cause of international trade and of comparative advantage of internationally acting firms, but its role has earlier been neglected because of problems of modeling market structures. The new trade theory (Krugman, 1979, $1980,1981)$ is the standard in analysis of economies of scale and product differentiation. To provide consumers more quality, a firm under monopolistic competition maintains spare capacities of production, marketing and R\&D in the same way as an oligopoly firm. This is risk-taking for the quality of consumption (Krugman et al., 2012).

The monopolistic competition model does not predict in which country firms locate, but a comparative advantage in producing the differentiated good will likely cause a country to export more of that good than it imports. Krugman placed geographical analysis in the economic mainstream. In his theory, transportation costs are the key features of the home market effect. A country with the large demand for a good shall, at equilibrium, produce a more than proportionate share of that good, and be a net exporter of it (ceteris paribus). Instead of spreading out evenly around the world, production will tend to concentrate in a few countries or regions, which will become densely populated but have higher levels of income. This is a feature in Krugman's new economic geography (1991) in terms of the Marshallian triad (1995).

\section{German Success Recipe by German HCs}

Chamberlin coined the term product differentiation to describe how a supplier is able to charge a greater amount for a product than perfect competition allows. Product differentiation means the process by which sellers distinguish their products from others by making them attractive to buyers. German HCs apply their own models of market leadership in which Schumpeter's innovation/entrepreneurship concept and Chamberlin's product differentiation concept is combined. The term HC was coined by Professor Simon (1990, p. 876) who was the first to use it as a title of publication in a scientific German management journal. The first English book was edited by Simon (1996) in which the question discussed was: How Germany, the relatively small EU country in comparison to the US and China, has sustained its position as the number one exporter for many years?

HCs are normally known only in their own area, by customers and suppliers, but not to the wider public (Simon, 2009, p. 15). These highly successful firms are often concealed behind a curtain of invisibility and business secrets. Often, but not always, they are family-owned. Their values are conservative: hard work, high performance, and high employee loyalty. Because HCs are often locating in small towns, their main deficit might be competition of young talents worldwide (Venohr \& Meyer, 2007, 2009). The main element of success by German HCs is a strong leadership with ambitious goals among the top three in global markets or to the 
number one on a own home continent. HCs produce high quality products that are ranked top in the world. For them, market leadership means "inner flame" to seek top performance, by unique products utilizing the in-depth knowledge about customers (Simon \& Jonason, 2013, p. 144). HCs accept the risk of being a single product manufacturer. That is the reason why they need to grow and operate close to their customers. Customers are important drivers for innovations. HCs "earn" their market leadership through performance and not through price aggression.

Knowledge has been differentiated in terms of explicit vs. tacit knowledge (Nonaka \& Takeuchi, 1995). Tacit context-specific knowledge, is difficult to create, transfer, or integrate via markets and, provides a rationale especially for German HCs to continue their amazing success-stories. Their tacit knowledge is valuable and provides competitive advantages, since it is less imitable, thanks to integrated marketing channels. The knowledge-creating theory focuses on the transformation and communication of what is already known tacitly by employees. HCs are excellent in that. Their strategic management system is auctorial, but their operative management system is participative generating superior performance embedded as "core competencies" within the firm (Hamel \& Prahalad, 1994). Such specialized resources are developed, not acquired, and should have low mobility as Venohr and Meyer (2007, 2009), Simon (2009) and Simon and Jonason (2013) have widely reported.

HCs have their advantage organizational learning and technological innovations (Simon, 2009). HCs have efficient contracts (social, legal) between owner-managers and employees with "different personal utility functions" (Gutenberg, 1951). Simon's writings (2009, 2014) on German HCs revolutionize the US-dominating business theories and practices. Schumpeter $(1934,1939)$ illuminated the difficulties that a company has in its efforts to combine market-driven business processes and continuous radical innovations. HCs are doing that. They have occupied global leadership positions despite their small size. In more general terms, the greatest innovations are likely to occur from the cross-fertilization of ideas and professions. This is how HCs are acting. They are highly Schumpeterian in their action. The HCs' business recipe is working well in international markets. HCs invest in internationalization early in their growth paths. The high co-dependence between HCs and their customers means also a high risk to their customers (Robinson, 1933). In spite of leadership, HCs are not oligopoly companies. In oligopoly, there are significant barriers to entry and, thereby, a monopoly power. A high level of co-dependence between HCs and their customer is not an entry barrier, since the customers have a free choice. HCs are "hidden" but they do small things better than their competitors meaning differential advantage (Alderson, 1957, 1965).

A market leadership position of a firm is highly rewarding but difficult to achieve in competitive globalized markets. In Drucker's analysis (1985) of entrepreneurial strategies, striving for leadership is the entrepreneurial strategy par excellence. This strategy is the core content of German HCs. Drucker's warning is that this strategy is the greatest gamble, making no allowances for mistakes and permitting no second chance. If it is successful, it is highly rewarding to a company. In average, the most rewarding entrepreneurial strategy is creative imitation - it is $90 \%$ of the whole. German HCs are the population of over 1,300 highly successful mid-sized firms. In Drucker's thinking, they are all gambling to achieve global market leadership. Their success rate as a population is near 90\% (Simon, 2009) that is not possible in gambling in average. Following their integrating model of marketing, HCs use to develop their own unique resource configuration models that are oriented toward customer needs. The key issue is the humble choice of markets segments, to make good business in any kind of goods and articles, not to follow trends or hit lists. 
The renaissance of monopolistic competition explains the survival of small firms in the global markets. HCs are best in that. They master the growth theory of customer-oriented firms. The empirical facts are unbelievable. Venohr (2010) has found that there are 1,500 firms in Germany that are world-market leaders (among three best) in their own segments. About 1,350 of them are HCs. About $90 \%$ of HCs act in B2B-markets and the most important industry group is the Machinery \& Equipment industry. HCs prefer to specialize in globally heterogeneous and marginal market segments that MNCs use to avoid, because of low growth prospects and high transaction costs. MNCs attempt to establish their market powers through strategic alliances in-house R\&D and portfolio investments abroad (Cross, 2000). HCs are mainly family firms having a strategic vision guiding marketing: to be the market leaders in their target markets. HCs are humble in constructing their marketing action plans, so that they are responsive to key customers (and competitors), in terms of Day $(1990,1992)$. The best success recipes are simple.

German and Finnish marketing professionals are both honest and serious. German marketers have succeeded to commercialize their reliability, credibility, and authenticity. For Finnish marketers, the same kind of qualities means a handicap in international arenas. Finland has excellent MNCs that are at the same level as German MNCs. The major difference is SMEs. HCs have attained a high customer loyalty worldwide with their technological superiority. Finnish SMEs in B2B technology industries are in serious crises and only some SMEs in global digital businesses (e.g. Rovio) have succeeded. German HCs have excellent marketing skills. They understand completely the model of monopolistic competition that is the theoretical foundation of marketing by Chamberlin. Gutenberg's genius monopolistic scope concept advises German marketers to avoid oligopolistic power games that have been devastating such a big firm as Nokia. The strategic management model (Figure 6) is constructed reflecting the German HCs way of acting, comparing to Abell (1980).

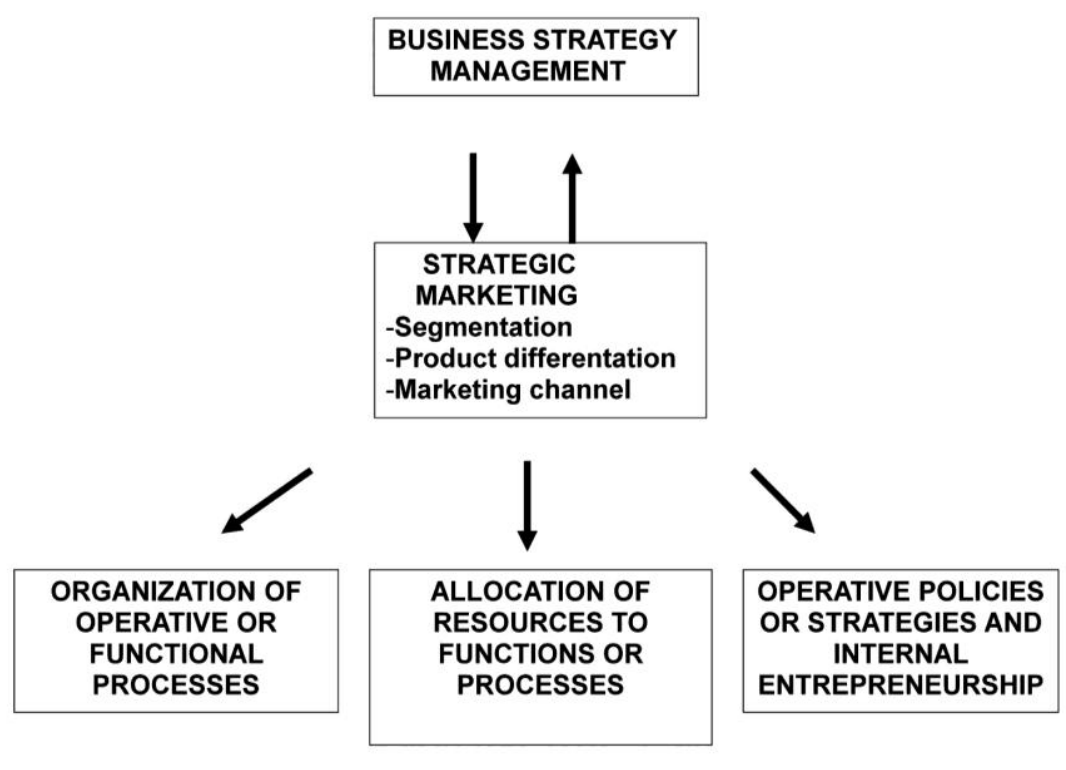

Figure 6. Strategic marketing model.

The customer-focused marketing concepts, such as segmentation, positioning and the product-life cycle, are ingredients of strategic marketing. These may involve positions based on price, premium quality, superior service, and innovativeness. HCs have verified the doctrine of continuous product/service innovations in "old" technology industries (mainly "machinenbau"). HCs have revitalized these industries by moving the 
competition logic away from price competition that dominates marketing of SMEs in "old" technology industries in most of EU-27-countries. German success recipe has been surprising, since monopolistically competitive industries are thought to be consumer service industries or retailing. One of the main reasons for Germany's competitiveness is excellent education (Schuman \& Himmelreich, 2011). The German marketing doctrine is based on "Globalia", global market orientation (Simon, 2014). The market leadership doctrine has been known by any businessman worldwide, since the 1970s when the Boston Consulting Group's (BCG) experience curve (1970) in Figure 7 was published. But successful applications are few.

\section{Unit costs of production}

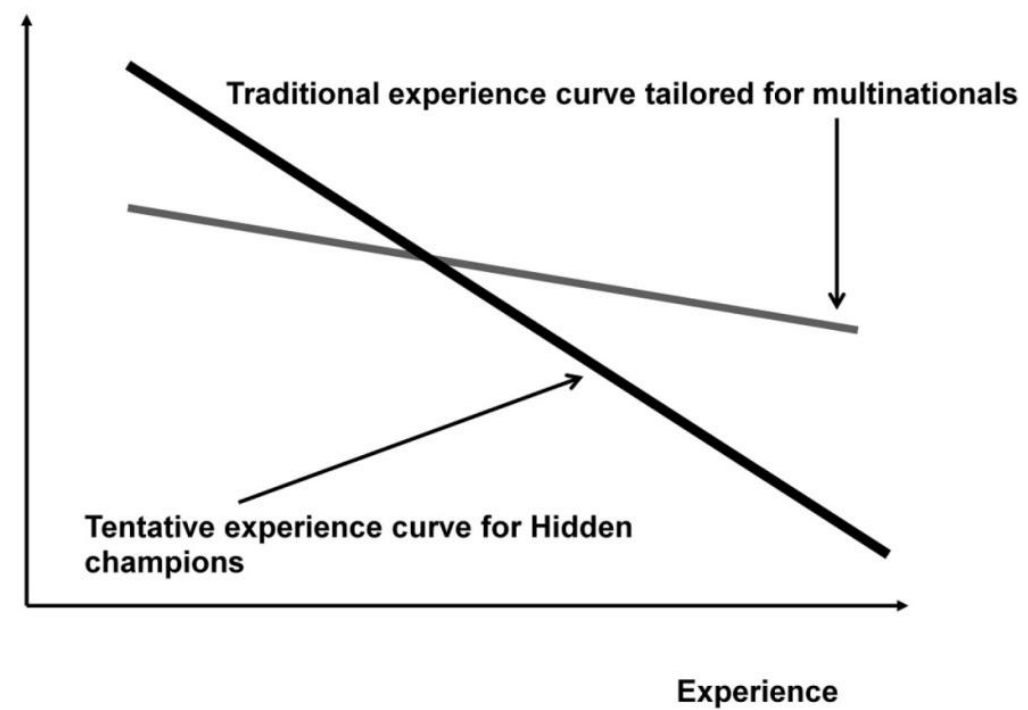

Figure 7. A visualization of the BCG model.

The BCG's original claim for the experience curve is: For each cumulative doubling of experience, total costs would decline roughly $10 \%$ to $15 \%$, because of economies of scale and learning-by-doing (Taylor, 1911), and that experience-based cost reduction can continue indefinitely. The practical contribution by BCG (1970) has been important. For the first time, there was a simple and parsimonious account of what competitive advantage is like, and how it is gained in the long run. The major difference between the BCG's experience curve and the HCs' global leadership recipe concerns pricing. HCs are not willing to win market shares by price wars. For HCs market, prices are the major market strategy element as Simon and Jonason (2013) elaborated. Their pricing strategy relies on price rigidity and product differentiation. This means a long-run commitment to serve customers and invent better products and services for them. Marketing channel is the key element of German success receipt. German companies prefer to internalize their marketing channels to keep customer secrets in a strict control.

Germany's customer-specific differentiation is not well known, since "global gurus" dominates the English literature and media. The paradox is that German firms have made a better version of the U.S. industrial method that helped the U.S. succeed for about hundred years until the 1980s. Sloan (1963), the famous CEO of GM, utilized Chamberlin's product differentiation in positioning. The U.S. management method is based on oligopoly models. The U.S. oligopoly theories are accountable to the mutual dependences between gigantic multinationals that are positioned in the mass-customized products and services and try to 
dominate core market segments by internalizing them. The majority of multinationals follow the U.S. oligopoly method, elaborated by Porter (1980, 1985). German HCs have top positions (Figure 8).

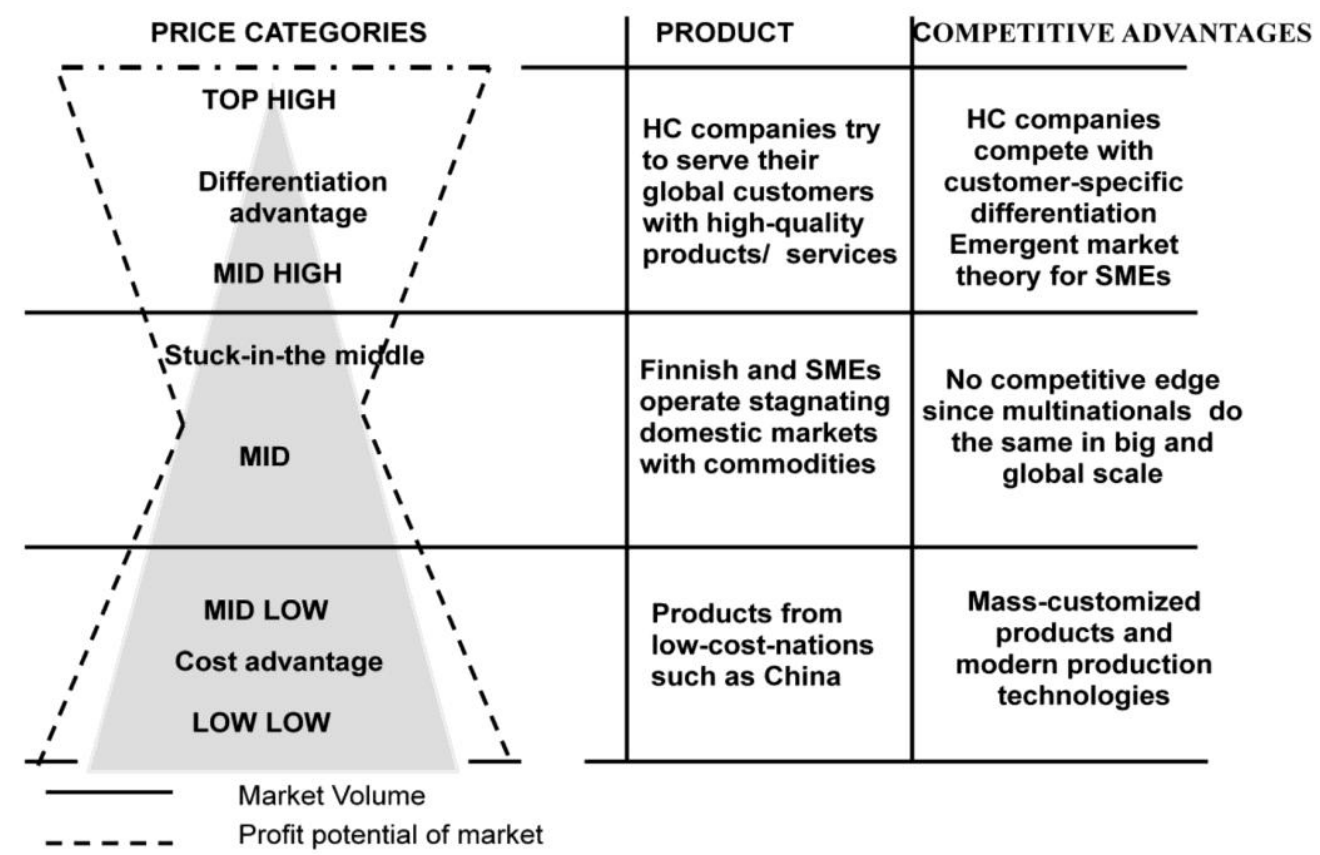

Figure 8. The Nordic niche-strategies.

\section{Conclusions}

Germany is the successful story in international trade in relation to the size of nation (e.g. population). In Germany, there are near 400,000 internationalized SMEs (Mittelstand) and about 100,000 of them have had FDI-operations (Venohr \& Meyer, 2007). Among big EU countries, Germany is dominating (Sinn, 2012) and France and Italy have serious difficulties to understand why German MNCs such as Volkswagen or Daimler are so excellent. German writers of international trade are not known worldwide. The US universities, e.g. Harvard and Chicago, fully dominate the international debate on the competition models. In the last few decades, the pendulum has swung back towards the German historical school of economics. Instead of relying on abstract neoclassical theories of international trade, the new trade theory has become the standard in analysis of economies of scale and product differentiation. Gutenberg's general management doctrine $(1951,1955,1969)$ is relevant to researches of Albach (1980) and Schmidt (2000), since the proponents of Chicago hide behind the curtains moral hazards such as the US financial crisis in the end of 2000s (Krugman, 2009, 2010).

The growth of MNCs in number has been remarkable rapid. In 2012, there were about 100,000 MNCs in the world and 900,000 foreign affiliates with total assets value about $\$ 57,000$ billion and sales about $\$ 33,000$ billion. MNCs as a firm group account for about $25 \%$ of the world GDP and their total share of the interregional trade of all commodities may be at the level of $80 \%$ (Retrieved from http://www.wto.org/english/news_e/pres13_e/pr688_e.htm). Including the intra-industry in which German HCs are world-champions, the distribution of trade is well in balance in Germany. Germany is exceptional, since the internationalization of medium-sized firms has been slow in most of the WTO-member countries. This is the reason why it is important to study carefully the global mobility barriers of SMEs. The high market turbulence in global markets provides a lot of market niches for medium-sized firms to conquer. This is an excellent 
foundation for their business strategies (Clifford \& Cavanagh, 1985). The case Germany is the best contemporary example of researches of Schuman and Himmelreich (2011). A successful recipe of the US, Germany, and China is to keep a balance between multinationals and the diversified SMEs (Figure 9).

Start-ups and growth firms ME contribute strongly to job creation in all continents. They are important because of the hollowing-out process of the big industrial firms Hamel (1991) has noticed in the US. This means a global reallocation of activities and can lead to the loss of skills and competitiveness of the Western economy. Hamel believed that a short-term strategic horizon may mislead firms to cut down their jobs to better their competitiveness on the expense of developing the people-embodied skills for the long-term leadership. The global economy is challenging. Substituting labor with capital and technology, along with shifting production to lower-cost regions has resulted in huge waves of firm downsizings in the EU, the US, and Japan (Baily, Bartelsman, \& Haltiwanger, 1996). The relocation of industrial activities out of the home-base is also called Wintelism (Hart \& Kim, 2002). The importance of mastering the manufacturing (Ramaswamy \& Rowthorn, 2001) is not perceived as the element of a nation's competitiveness. The formerly critical skills of the regional clusters may become commodities, when MNCs relocate their manufacturing worldwide. In small and open countries like Finland, this kind of misinterpretation of the IO theories may lead towards the economic disaster.

HCs apply their own models of market leadership in which Schumpeter's innovation/entrepreneurship concept and Chamberlin's/Gutenberg's product differentiation concept are combined as Venohr and Meyer (2007, 2009), Simon (2009), and Simon and Jonason (2013) have widely reported. With about 90\% success rate, $\mathrm{HCs}$ are competing away their main competitors in the various market niches. Their behavior is certainly different from the dominant oligopoly behavior. It is possible to imply that they follow the key principles of monopolistic competition that Krugman $(1979,1980,1981)$ has elaborated in terms of international intra-industry trade. HCs are also theoretically "hidden" since most of monopolistically competing industries are consumer industries and the market scope is national or Pan-American or Pan-European.

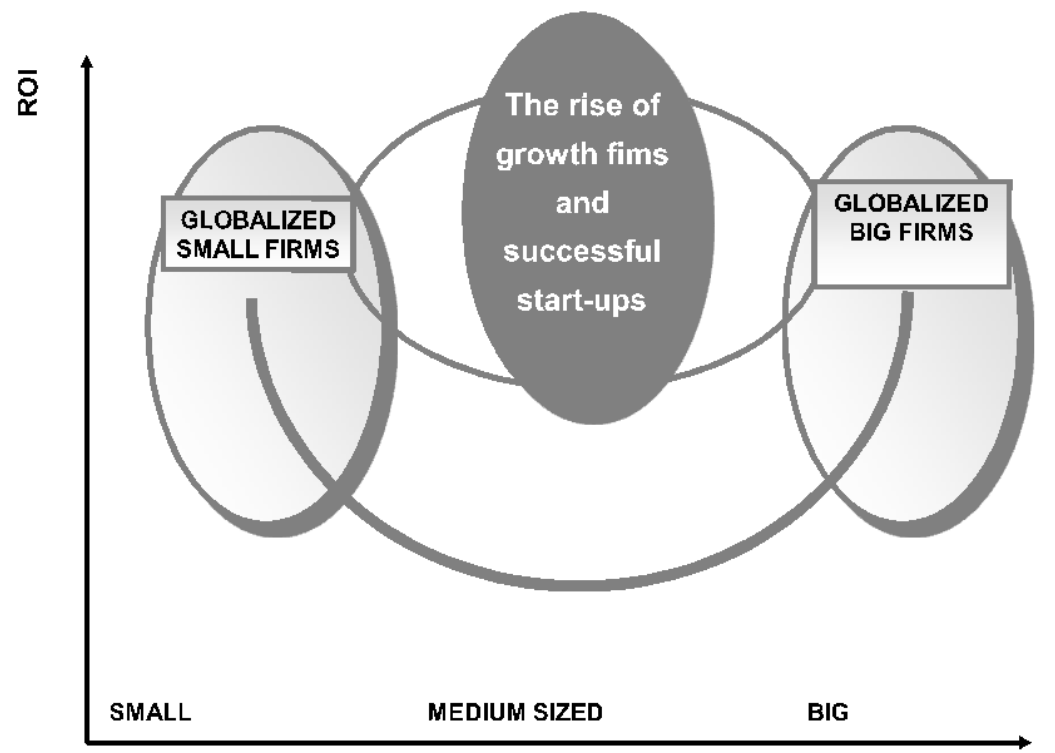

FIRM SIZE

Figure 9. Various size-classes of firm. 
There is a research gap both in theoretical and empirical research concerning intra-industry trade and B2B-industries. The major reason for that is that these industries are extremely heterogeneous and the statistical criteria are different in different countries. It is time-consuming to collect up-to-date data-bases of that sort of businesses, especially in international context. In order to testify the main hypothesis, authors need proper data-bases.

The theoretical-methodological reason is dominance of mathematics in economics. The revolution of game theory, e.g. Nash equilibrium concept (Shoham \& Leyton-Brown, 2009), together with econometrics as the main method in empirical analyses led to highly complex empirical models of technological changes, merger analyses, entry-exit models, and market power analysis. The influential economists of the Chicago School have not been fascinated to analyze the real completive circumstances in markets, since their worries were more excessively low profitability under the circumstances of perfect competition, when only normal profit is available. The Chicago economists were hostile to the US antitrust laws, although their major problem was and still is the abstract modeling that odds real market conditions. They succeeded to decline the comparative merits of Chamberlin (Archibald, 1961, 1963). The theory of monopolistic competition was seen as a departure from the ideal of perfect competition and Pareto optimality, e.g. Kaldor (1983). Stigler (1946, $1968,1976,1978,1983)$ urged economists to use the orthodox price-theory.

Friedman (1953) extolled the virtues of a free market system with minimal intervention: "The market is always right" (Ebenstein, 2007) or "Market exchange is an ethic in itself, capable of acting as a guide for all human action" (Harvey, 2005). Galbraith's view (1956, 1958, 1967, 1973) of post-war capitalism is challenging the Chicago economists. According to Galbraith's critics, modern capitalism is dominated by large firms that invest heavily in manipulative advertising to create artificial wants and barriers. His concept of countervailing power is a parallel concept to Schumpeter's notion of trustified capitalism. Countervailing power describes the level of collusion between large firms and the government (Galbraight, 1956, 1958, 1967). Galbraith (1973) found that the static economic efficiency is a major barrier to innovate. Large firms grow because of technological imperative. Their size owes to economies of scale, large R\&D budgets, and the unique ability to incorporate new technologies. The paradox is that the scientist Friedman supported the idea of perfect market contestability, but the advisor of the US president Reagan said that his view was simply "money talks". The debate between the Harvard SCP and the Chicago School occurred largely within these guidelines (Hovenkamp, 2009). A paradox is that Porter $(1980,1985)$ became world-known by replicating Chamberlin's ideas such as the concept of differentiation without giving credits to Chamberlin.

In reality, monopolistic markets are the most common in international trade. A realistic pricing strategy is important for internationally operating firms of which German corporate sector is an excellent example. As Simon (1990, 1996, 2009) and Venohr and Meyer (2007, 2009) have noticed, German HCs that are mainly operating in B2B-industries are unbelievable success stories in global markets. In Germany, the theories of competition are based on the nations' own scientists. In most of neoliberal countries, there are profound crisis in competition theories (Colander, 2008). The SCP was discounted by game theorists mainly from the University of Chicago. In the 1980s, the SCP was taken over by game theoreticians in the lead of Porter, many universities suddenly stopped doing empirical research under the SCP and relied on Porter $(1980,1985)$ that are simplifications of the SCP and intended for practical business managers. However, the SCP provided a well-verified framework making for empirical and statistical analyses of how firms are really behaving. This 
was one of the arguments why the SCP was the key instrument to implement the anti-trust legislation in the US from the 1950s to the 1970s.

Because of the Chicago campaign against the SCP, most of economists rely on perfect competition and on econometrics as the main empirical research method. As Krugman $(2009,2010)$ has explained that the global financial crisis is the result of the anti-competitive behavior of financial institutions in the US. This kind of huge market failure is the most striking evidence on a market failure and on the fact that the US regulatory agencies should still apply the logic of the SCP analysis a natural monopoly with an optimal size and the lowest possible cost is not inefficient because of public ownership as the Chicago cadre uses to claim. This kind of realistic policy is well implemented in Germany where the current and earlier state-owned firms contribute strongly to Germany's national economy and have succeeded extremely well in the global markets. In most of the developing countries, natural monopolies may behave as real monopolies that can be one of the major barriers in the growth of local entrepreneurship (Lahti, 2010, 2011, 2012).

\section{References}

Abell, D. (1980). Defining the business: The starting point of strategic planning. Englewood Cliffs: Prentice-Hall, Inc..

Aghion, P., \& Howitt, Per (1998). On the macroeconomic effects of major technological change in general purpose technologies and economic growth. Cambridge: MIT Press.

Albach, H. (1980). Average and best-practice production functions in German industry. The Journal of Industrial Economics, 29(1), 55-70.

Alderson, W. (1957). Marketing behavior and executive action. Homewood: Richard D. Irwin, Inc..

Alderson, W. (1965). Dynamic marketing behavior: A functionalist theory of marketing. Homewood: Richard D. Irwin, Inc..

Andersen, S. (2009). Schumpeter's evolutionary economics: A theoretical, historical and statistical analysis of the engine of capitalism. London: Anthem Press.

Archibald, C. (1961). Chamberlin versus Chicago. Review of Economics and Statistics, 28, 2-28.

Archibald, C. (1963). Reply to Chicago. Review of Economics and Statistics, 30, 68-71.

Arrow, K., \& Hahn, F. (1971). General competitive analysis. San Francisco: Holden-Day.

Baily, M., Bartelsman, E., \& Haltiwanger, J. (1996). Downsizing and productivity growth: Myth or reality? Small Business Economics, 8(4), 259-278.

Bain, J. (1951). Relation of profit rate to industry concentration: American manufacturing, 1936-1940. Quarterly Journal of Economics. 65(3), 293-324.

Bain, J. (1956). Barriers to competition. Cambridge: Harvard University Press.

Baumol, W. (1982). Contestable markets: An uprising in the theory of industry structure. American Economic Review, 72, 1-15.

Bellante, D. (2004). Edward Chamberlin: Monopolistic competition and Pareto optimality. Journal of Business \& Economics Research, 2(4), 17-26.

Boston Consulting Group. (1970). Perspectives on experience curve. Boston: Boston Consulting Group, Inc..

Brue, S., \& Grant, R. (2008). The evolution of economic thought. New York: McGraw-Hill/Irwin.

Carroll, C., Pandian, J., \& Thomas, H. (1994). Assessing the height of mobility barriers: A methodology and an empirical test in the U.K. retail grocery industry. British Journal of Management, 5(1), 1-18.

Chamberlin, E. H. (1933). The theory of monopolistic competition. Cambridge: Harvard University Press.

Chamberlin, E. H. (1937). Monopolistic or imperfect competition? The Quarterly Journal of Economics, 51(4), 557-580.

Chamberlin, E. H. (1948). An experimental imperfect market. Journal of Political Economy, 56(2), 95-108.

Chamberlin, E. H. (1951). Impact of recent monopoly theory on the Schumpeterian system. Review of Economics and Statistics, $33,133-138$.

Chamberlin, E. H. (1957). Towards a more general theory of value. New York: OUP.

Chamberlin, E. H. (1965). The theory of monopolistic competition: A re-orientation of the theory of value (8th ed.). Cambridge: Harvard University Press.

Chandler, A. (1962). Strategy and structure. Cambridge: MIT Press. 
Chandler, A. (1990). Scale and scope. The dynamics of industrial capitalism. Cambridge: The Belknap Press of Harvard University Press.

Clifford, D., \& Cavanagh, D. (1985). The winning performance: How American's high growth mid-sized companies succeed. New York: Bantam Doubleday Dell Pub.

Coase, R. (1960). The problem of social cost. Journal of Law and Economics, 3, 1-44.

Coase, R. (1987). The nature of the firm. In L. Putterman (Ed.), The economic nature of the firm. Cambridge: Harvard University Press.

Coase, R. (1988). The firm, the market, and the law. Chicago: University of Chicago Press.

Coase, R. (1998). The new institutional economics. American Economic Review, 88(2), 72-74.

Colander, D. (2008). Microeconomics (7th ed.). New York: McGraw-Hill/ Irwin.

Cool, K. O., \& Schendel, D. (1987). Strategic group formation and performance: The case of the U.S. Pharmaceutical industry 1963-1982. Management Science, 33(9), 1102-1124.

Cross, A. (2000). Modes of internationalization. In M. Tayeb (Ed.), International business, theories, policies and practices. London: Harlow, Pearson Education.

Day, G. (1990). Market-driven strategy: Processes for creating value. New York: The Free Press.

Day, G. (1992). Marketing's contribution to the strategy dialogue. Journal of the Academy of Marketing Science, 10, 323-329.

De Jong, H., \& Shepherd, W. (2007). Pioneers of industrial organization: How the economics of competition and monopoly took shape. London: Edward Elgar Publishing Ltd.

Dixit, A., \& Stiglitz, J. (1977). Monopolistic competition and optimum product diversity. American Economic Review, American Economic Association, 67(3), 297-308.

Drucker, P. (1985). Innovation and entrepreneurship: Practice and principles. London: Heinemann.

Ebenstein, L. (2007). Milton Friedman: A biography. New York: Palgrave Macmillan.

Eisenhardt, K. (1989). Agency theory: An assessment and review. Academy of Management Review, 14(1), 57-74.

Foster, N., \& Stehrer, R. (2013). International fragmentation of production, trade and growth: Impacts and prospects for EU member states (European Economy. Economic Papers 484, April 2013, Brussels).

Friedman, M. (1953). Essays in positive economics. Chicago: University of Chicago Press.

Galbraith, J. (1956). American capitalism: The concept of countervailing power. Boston: Houghton Mifflin.

Galbraith, J. (1958). The affluent society. Boston: Houghton Mifflin.

Galbraith, J. (1967). The new industrial state. Princeton: Princeton University Press.

Galbraith, J. (1973). Economics and the public purpose. Boston: Houghton Mifflin.

Goodwin, N., Nelson, J., Ackerman, F., \& Weisskopf, T. (2009). Microeconomics in context (2nd ed.). New York: Sharpe M. E. Publishers Inc..

Gutenberg, E. (1951). Grundlagen der Betriebswirtschaftslehre. Band 1: Die Produktion (Fundamentals of business administration. Volume 1: The production). Berlin: Springer-Verlag 1951, 1983 (24. Auflage)

Gutenberg, E. (1955). Grundlagen der Betriebswirtschaftslehre. Band 2: Der Absatz (Fundamentals of business administration. Volume 2: The sales). Berlin: Springer-Verlag 1955, 1984 (17. Auflage).

Gutenberg, E. (1969). Grundlagen der Betriebswirtschaftslehre. Band 3: Die Finanzen (Fundamentals of business administration. Volume 3: The finance). Berlin: Springer-Verlag 1969, 1980 (8. Auflage).

Hamel, G. (1991). Collaborate to compete. Strategic Management Journal, 12, 83-103.

Hamel, G., \& Prahalad, C. (1994). Competing for the future. Cambridge: Harvard University Press.

Haour, G. (2004). Resolving the innovation paradox: Enhancing growth in technology companies. New York: Palgrave Macmillan.

Hart, J., \& Kim, S. (2002). Explaining the resurgence of U.S. competitiveness: The rise of Wintelism. The Information Society, 18, $1-12$.

Harvey, D. (2005). A brief history of neoliberalism. Oxford: Oxford University Press.

Hatten, K. (1974). Strategic models in the brewing industry (Unpublished doctoral dissertation, Purdue University).

Helpman, E., \& Krugman, P. (1985). Trade policy and market structure. Cambridge: MIT Press.

Hoskisson, R. E., Hitt, M. A., Wan, W. P, \& Yiu, P. (1999). Theory and research in strategic management: Swings of a pendulum. Journal of Management, 25(3), 417-456.

Hovenkamp, H. (2009). United States competition policy in crisis: 1890-1955. Minnesota Law Review, 94, 311-367. 
Hunt, M. (1972). Competition in the major home appliance industry, 1960-1970 (Unpublished Ph.D. dissertation, Harvard University).

Innovation's Golden Goose. (2002). The economist. Retrieved from www.economist.com/node/1476653

Jones, A., \& Sufrin, B. (2010). EU competition law: Text, cases and materials. Retrieved from http://www.amazon.com/EU-Competition-Law-Cases-Materials/dp/0199572739

Kaldor, N. (1938). Professor Chamberlin on monopolistic and imperfect competition. Quarterly Journal of Economics, 52(3), 513-529.

Killström, P. (2005). Strategic groups and performance of a firm. Towards a new competitive environment in the Finnish telecommunication industry (doctoral dissertation, Helsinki School of Economics, A-248, Helsinki).

Knight, F. (1920). Risk, uncertainty, and profit. Chicago: University of Chicago Press.

Kreikebaum, H. (2000). The impact of Gutenberg's theory of organisation upon modern organisational conceptions in theory of the firm. In H. Albach, K. Brockhoff, E. Eymann, P. Jungen, M. Steven, \& A. Luhmer (Eds.), Erich Gutenberg's foundations and further developments (pp. $\quad$ 88-103). Retrieved from http://www.amazon.com/Theory-Firm-Gutenbergs-Foundations-Developments/dp/3642640745

Krugman, P. (1979). Increasing returns, monopolistic competition, and international trade. Journal of International Economics, 9 , 469-479.

Krugman, P. (1981). Intra-industry specialization and the gains from trade. Journal of Political Economy, 89, 959-973.

Krugman, P. (1991). Geography and trade. Cambridge: MIT Press.

Krugman, P. (1995). Development, geography, and economic theory. Cambridge: MIT Press.

Krugman, P. (2009). Financial policy despair. The New York Times. Retrieved from www.economicshelp.org/.../paul-krugman-on-financial-crisis.html

Krugman, P. (2010). Things everyone in Chicago knows. The New York Times. Retrieved from http://krugman.blogs.nytimes.com/2010/06/03/things-everyone-in-chicago-knows/?_r=0

Krugman, P. R., Obstfeld, M., \& Melitz, M. J. (2012). International economics: Theory and policy (9th ed.). Boston: Pearson Addison-Wesley.

Krugman, P.(1980). Scale Economies, product differentiation, and the pattern of trade. American Economic Review, 70, $950-959$.

Krugman, P., \& Wells, R. (2009). Microeconomics (2nd ed.). New York: Worth Publisher.

Kumar, N. (1990). Mobility barriers and profitability of multinational and local enterprises in Indian manufacturing. The Journal of Industrial Economics, 38, 449-61.

Kumar, N. (1994). Multinational enterprises and industrial organization: The case of India. New Delhi: Sage Publications.

Kumar, N. (1998). Globalization, foreign direct investment and technology transfers: Impacts on and prospects for developing countries. New York: Routledge.

Lahti, A. (1983). Strategy and performance of a firm, an empirical investigation in the knitwear industry in Finland 1969-1981 (doctoral dissertation). Helsinki School of Economics, pp. A-41.

Lahti, A. (2010). Globalization \& the Nordic success model-Part I. Retrieved from http://bookboon.com/uk/student/economics/globalization-the-nordic-succes-model-part-i

Lahti, A. (2011). Globalization \& the Nordic Success Model-Part 2. Retrieved from http://bookboon.com/uk/student/economics/globalization-the-nordic-succes-model-part-ii

Lahti, A. (2012). Innovation competition in global markets and Schumpeter's entrepreneur. Saarbrücken: LAP LAMBERT $\begin{array}{llllll}\text { Academic } & \text { Publishing } & \mathrm{GmbH} & \text { Co. } & \text { Retrieved }\end{array}$ https://www.morebooks.de/store/gb/book/innovation-competition-in-global-markets-and-schumpeter-s-entrepreneur/isbn/978 $-3-8484-9420-0$

Lazonick, W. (1991). Business organization and the myth of the market economy. Cambridge: MIT Press.

Leontief, W. (1986). Input-output economics (2nd ed.). New York: Oxford University Press.

Linder, S. (1961). Trade and trade policy for development. Stockholm: Almqvist \& Wiksell.

Lintunen, L. (2000). Who is the winner entrepreneur? An epistemological study of the Schumpeterian entrepreneur (doctoral dissertation, Helsinki School of Economics, series 2000: A-180, Helsinki).

List, F. (1841). Nationale System der politischen Ökonomie. Retrieved from http://link.springer.com/chapter/10.1007\%2F978-3-531-90400-9_69

Loasby, B. (1999). Knowledge, institutions and evolution in economics. London: Routledge.

Loewenberg, S. (2009). News \& views: The Bayh-Dole act: A model for promoting research translation? Molecular Ontology, 3, 91-93. 
Luukkainen, P. (2012). Strateginen ryhmä toimiala-analyysin osana-empiirinen tutkimus Suomen kasvihuonetoimialalta (Strategic groups as part of industry analysis-An empirical study of the Finnish greenhouse industry) (doctoral dissertation, Aalto University publication series 130/2012).

Machlup F., \& Penrose, E. (1950). The patent controversy in the nineteenth century. Journal of Economic History, 10(1), 1-29.

Marshall, A. (1920). Principles of economics. London: Macmillan and Co.

Mason, E. S. (1957). Economic concentration and the monopoly problem. Cambridge: Harvard University Press.

McGee, J., \& Thomas, H. (1986). Strategic groups: Theory, research and taxonomy. Strategic Management Journal, 7, $141-160$.

McGee, J., \& Thomas, H. (1989). Strategic groups: A further comment. Strategic Management Journal, 10, 105-107.

Newman, H. H. (1973). Strategic groups and the structure-performance relationships: A study with respect to the chemical process industries (Unpublished Ph.D. dissertation, Harvard University).

Nonaka, I., \& Takeuchi, H. (1995). The knowledge-creating company. Oxford: Oxford University Press.

North, D. (1993). Institutions, institutional change and economic performance. Cambridge: Cambridge University Press.

Ohlin, B. (1933). Interregional and international trade. Cambridge: Harvard University Press.

Patton, G. R. (1976). A simultaneous equation model of corporate strategy: The case of the U.S. brewing industry (Unpublished doctoral dissertation, Purdue University).

Pindyck, R. S., \& Rubinfeld, D. L. (2009). Mikroökonomie (Microeconomics). München: GRIN Verlag.

Porter, M. (1973). Consumer behavior, retail power, and manufacturing strategy in consumer goods industries (Unpublished Ph. D. dissertation, Harvard University).

Porter, M. (1980). Competitive strategy. New York: Free Press.

Porter, M. (1985). Competitive advantages. New York: Free Press.

Ramaswamy, R., \& Rowthorn, R. (2001). Does manufacturing matter? Harvard Business Review, November-December, 2-3.

Ricardo, D. (1817). On the principles of political economy and taxation. London: John Murray.

Robinson, J. (1933). The economics of imperfect competition. Cambridge: Harvard University Press.

Romer, P. (1989). Increasing returns and new developments in the theory of growth. Chicago: University of Chicago Press.

Romer, P. (1990). Endogenous technological change. Journal of Political Economy, 98(5), 71-102.

Rumelt, R., Schendel, D., \& Teece, D. (1991). Strategic management and economics. Strategic Management Journal, 12, 5-29.

Salimäki, M. (2003). Suomalaisen design-teollisuuden kansainvälinen kilpailukyky ja kansainvälistyminen (International competitiveness and competitive advantage of the Finnish design-industry) (doctoral dissertation, Helsinki School of Economics, A-220, Helsinki).

Samuels, W. (1989). Determinate solutions and valuational process. Journal of Post Keynesian Economics, 11(4), 531-546.

Samuelson, P. (1947). Foundations of economic analysis. Cambridge: Harvard University Press.

Sandmo, A. (2011). Economics evolving: A history of economic thought. Princeton: Princeton University Press.

Scherer, F. (1970). Industrial market structure and economic performance. Chicago: Rand McNally and Company.

Scherer, F. (1999). New perspectives on economic growth and technological innovation. Washington, D.C.: Brookings Institution Press.

Scherer, F., \& Ross, D. (1990). Industrial market structure and economic performance. Boston: Houghton Mifflin Company.

Schmidt, R. H. (2000). Erich Gutenberg and the theory of the firm in theory of the firm. In H. Albach, K. Brockhoff, E. Eymann, P. Jungen, M. Steven, \& A. Luhmer (Eds.), Erich Gutenberg's foundations and further developments. Retrieved from http://www.amazon.com/Theory-Firm-Gutenbergs-Foundations-Developments/dp/3642640745

Schuman, M., \& Himmelreich, C. (2011). How Germany became the China of Europe. Time, 177-179, 52-55.

Schumpeter, J. (1934). The theory of economic development. Cambridge: Cambridge University Press.

Schumpeter, J. (1939). The business cycles. New York: McGraw-Hill.

Schumpeter, J. (1942). Capitalism, socialism and democracy. New York: McGraw-Hill.

Schumpeter, J. (1994). History of economic analysis. Oxford: Oxford University Press.

Shoham, Y., \& Leyton-Brown, K. (2009). Multiagent systems: Algorithmic, game-theoretic, and logical foundations. New York: Cambridge University Press.

Simon, H. (1960). The new science of management decisions. New York: Harper \& Row.

Simon, H. (1979). Rational decision making in business organizations. American Economic Review, 69(4), $493-513$.

Simon, H. (1990). Hidden champions: Speerspitze der deutschen Wirtschaft (Hidden champions: The spearhead of the German economy). Wiesbaden: Zeitschrift für Betriebswirtschaft (ZfB). 
Simon, H. (1996). Hidden champions: Lessons from 500 of the world's best unknown companies. Boston (Mass.): Harvard Business School Press.

Simon, H. (2009). Hidden champions of the 21st century. New York: Springer.

Simon, H. (2014). Hidden champions-Aufbruch nach Globalia (Hidden champions-towards global markets). Frankfurt: Campus Verlag.

Simon, H., \& Jonason, A. (2013). Hidden champions: Framgångsstrategier hos dolda världsledande företag (Hidden champions: Success strategies of hidden market leaders in global markets) (Studentlitteratur).

Sinn, H. W. (2012). Die Target Fall—Gefahren für unser Geld und unsere Kinder (The target trap—dangers for our money and our children). Munich: Hanser.

Sloan, A. (1963). My work with general motors. New York: Doubleday.

Smith, A. (1776). An inquiry into the nature and causes of the wealth of nation. New York: Random House, Inc..

Stigler, G. (1946). The theory of price. Macmillan: New York.

Stigler, G. (1976). Do economists matter? Southern Economic Journal, 42, 347-354.

Stigler, G. (1978). The literature of economics: The case of the kinked oligopoly demand curve. Economic Inquiry, 16, $185-204$.

Stigler, G. (1983). Nobel lecture: The process and progress of economics. Journal of Political Economy, 91, 529-545.

Stigler, G. J. (1968). The organization of industry. Chicago: University of Chicago Press.

Taylor, F. (1911). The principles of scientific management. New York: Harper Bros.

Thomas, H., \& Venkatraman, N. (1988). Research on strategic groups: progress and prognosis. Journal of Management Studies, $25,537-555$.

United Nations., United Nations Conference on Trade and Development., \& World Trade Organization Secretariat. (2014). World investment report. Retrieved from http://www.wto.org/english/news_e/pres13_e/pr688_e.htm

Venohr, B. (2010). The power of uncommon sense management principles-The secret recipe of German Mittelstand. Retrieved from www.druckersociety.at/.../2010/.../Venohr_101118_PP

Venohr, B., \& Meyer, K. E. (2007). The German Miracle keeps running: How Germany's hidden champions stay ahead in the global economy (Working Papers).

Venohr, B., \& Meyer, K. E. (2009). Uncommon common sense. Business Strategy Review, 20(1), 39-43.

Williamson, O. (1985). The economic organization firms, markets and policy control. New York: Harvester Wheatsheaf Books.

Williamson, O. (1987). The economic institutions of capitalism, firms, market and rational contracting. New York: Free Press.

Williamson, O. (1990). The firm as a nexus of treaties: An introduction. In M. Aoki, \& B. Gustavsson (Eds.), The firm as a nexus of treaties (pp. 1-25). London: Sage Publications.

Williamson, O. (1991). Strategizing, economizing, and economic organization. Strategic Management Journal, 12 , 75-94.

Wintle, J. (2002). Makers of nineteenth century culture: 1800-1914. New York: Routledge. 